\title{
Dikkat Eksikliği Hiperaktivite Bozukluğu Olan Çocuk ve Ergenlerde Serum Anti-oksidan Vitamin Düzeyleri
}

\author{
Serum Anti-oksidan Vitamin Levels in Children and Adolescents with Attention Deficit Hyperactivity \\ Disorder
}

\author{
(D) Müslüm Kul${ }^{1}$, (1) Mahmut Zabit Kara², (1) Saniye Önol ${ }^{3}$, (1) Fatih Ünal ${ }^{4}$ \\ ${ }^{1}$ Mersin Şehir Eğitim ve Araştırma Hastanesi, Çocuk ve Ergen Psikiyatrisi Kliniği, Mersin, Türkiye \\ ${ }^{2}$ Sağlık Bilimleri Üniversitesi Antalya Eğitim ve Araştırma Hastanesi, Çocuk ve Ergen Psikiyatrisi Kliniği, Antalya, Türkiye \\ ${ }^{3}$ Hacettepe Üniversitesi Tıp Fakültesi, Beslenme ve Metabolizma Laboratuvarı, Ankara, Türkiye \\ ${ }^{4}$ Hacettepe Üniversitesi Tip Fakültesi, Çocuk ve Ergen Ruh Sağllğı Anabilim Dalı, Ankara, Türkiye
}

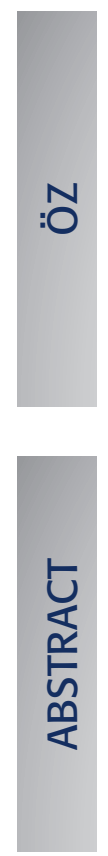

Amaç: Dikkat eksikliği ve hiperaktivite bozukluğu (DEHB) etiyolojisi henüz tam olarak anlaşılamamıştır. Son dönemlerde yapılan çalışmalarda bu hastalıkta oksidatif yükün arttığı ve anti-oksidan savunmaların zayıfladığı bildirilmiştir. Bu çalışmanın amacı; DEHB tanısı konan çocuk ve ergenler ile sağlıklı kontrol grubunu, anti-oksidan savunma mekanizmalarının önemli bir bileşeni olan serum anti-oksidan vitamin düzeyleri açısından karşılaştırmaktır.

Gereç ve Yöntem: Yapılan klinik değerlendirme ve kullanılan ölçek sonuçları ile DEHB tanısı konan 39 çocuk ve ergen, yaş ve cinsiyet açısından benzer 25 sağlıklı kontrol ile serum vitamin $A, C$ ve $E$ düzeyleri açısından karşılaştırıldı.

Bulgular: DEHB grubunda A, C ve E vitamin düzeyleri sağlıklı kontrollere benzer bulunmuştur.

Sonuç: Çalışmamızın sonuçları serum anti-oksidan vitamin düzeylerinin DEHB hastalarında sağlıklı kontrollerden farklı olmadığını göstermiştir. Bununla birlikte bu konuda daha geniş gruplar ile yapılacak çalışmalara ihtiyaç vardır.

Anahtar Kelimeler: DEHB, anti-oksidan savunma, serum vitamin düzeyleri

Objectives: The etiological causes of attention deficit and hyperactivity disorder (ADHD) are not fully understood yet. Recent studies have reported that the anti-oxidant activity is reduced and the oxidative stress is increased in ADHD. The aim of this study is to compare serum antioxidant vitamin levels, which are important components of anti-oxidant defense system, between the children and adolescents with ADHD and healthy controls.

Materials and Methods: Serum levels of vitamin A, C and E were compared between 39 children and adolescents diagnosed with ADHD and 25 healthy controls with similar age and gender by using clinical evaluation and rating scales.

Results: There were no significant differences in serum vitamin A,C and E levels between ADHD and control groups.

Conclusion: This study concludes no significant effect of serum A, C and E vitamin levels on ADHD. There is still need for future studies on larger samples.

Keywords: ADHD, anti-oxidant defense, serum levels of vitamin

\section{Giriş}

Dikkat eksikliği hiperaktivite bozukluğu (DEHB) çocukluk çağının en sık psikiyatrik hastalı̆̆ı olup etiyolojisi tam olarak anlaşılmamıştır. Son yıllarda DEHB'nin nörobiyolojik temellerine yönelik araştırmaların sayısı ve elde edilen veriler artmaktadır. Bu amaçla yapılan çalışmalarda araştırılan konulardan bir tanesi de oksidatif metabolizmadır.
Vücudumuzda indirgenme tepkimeleri sonucunda oksidan denilen atık moleküller ortaya çıkar. Oksidan moleküllerin büyük bölümünü, reaktif oksijen türevleri olarak adlandırılan ve oksijenden oluşan serbest radikaller oluşturur. ${ }^{1} \mathrm{Bu}$ moleküller son derece toksik olup hücrenin temel yapılarını etkileyerek hücre ölümüne kadar varabilen hasara yol açarlar. ${ }^{2}$ Oksidanların oluşum hızı ile bunları etkisizleştiren antioksidanlar arasındaki dengenin oksidanlar lehine bozulması,

Yazıșma Adresi/Address for Correspondence: Dr. Mahmut Zabit Kara, Sağlık Bilimleri Üniversitesi Antalya Eğitim ve Araștırma Hastanesi, Çocuk ve Ergen Ruh Sağlığı Kliniği, Antalya, Türkiye

E-posta: mahmutz.kara@yahoo.com ORCID: orcid.org/0000-0002-7727-3838

Geliș Tarihi/Received: 18.07.2013 Kabul Tarihi/Accepted: 09.06.2017

OTelif Hakkı 2019 Türkiye Çocuk ve Genç Psikiyatrisi Derneği / Çocuk ve Gençlik Ruh Sağlğı̆ Dergisi, Galenos Yayınevi tarafindan yayınlanmıștr. 
hücreleri oksidanların zararlı etkilerine açık hale getirir. Oksidanların artışı ile hücre işlevleri üzerinde yaptıkları biyolojik hasar için "oksidatif stres" tanımı kullanılır. ${ }^{3}$ Son yıllarda yapılan çeşitli çalışmalarda şizofreni, bipolar afektif bozukluk, depresyon, otizm ve DEHB gibi birçok psikiyatrik hastalıkta nitrik oksit, malondialdehit gibi bazı oksidan moleküllerin arttığı, buna karşın glutatayon peroksidaz, süperoksit dizmütaz gibi bazı anti-oksidan moleküllerin ise azaldığı gösterilmiş olup bunun da hastalıkların oluşumunda rol oynayabileceği öne sürülmüştür. ${ }^{4-10}$ Erişkin DEHB grubunda yapilan bir çalışmada ise total anti-oksidan seviye (TAS), total anti-oksidan seviyenin (TOS) ve oksidatif stres indeksi (TOS/TAS) kontrol grubuna göre anlamlı olarak yüksek olduğu bulunmuştur. Yüksek TAS değerleri artmış oksidatif yükün dengelenmeye çalışılması ile ilişkilendirilmiş, bu artışa rağmen DEHB grubunda oksidatif balansın bozulmuş olduğu saptanmıştır. ${ }^{11}$

Oksidatif stresin etkisi ile ilgili en güçlü varsayım, oksidanların zarla ilişkili proteinler ile tepkimeye girmelerinden kaynaklanmaktadır. Zar yapısındaki bozulmanın nöronların reseptörlerini de etkileyebileceği ve bunun da nöron işlevlerinin bozulmasına neden olabileceği öne sürülmüştür. ${ }^{12}$ Ayrıca nöronal hücre zarlarında meydana gelen bozulmaların norepinefrin ve dopamin başta olmak üzere nörotransmitterler ile ilgili sorunlara neden olabileceği bildirilmiştir. ${ }^{13-14}$ Serbest radikallerin oluşumunu ve bunların meydana getirdiği hasarı önlemek için vücutta anti-oksidan savunma sistemleri bulunur. Enzimatik yapıdaki anti-oksidanlar hücre içinde etkinlik gösteren çeşitli enzimlerden oluşur. Enzimatik yapıda olmayan başlıca anti-oksidan moleküller besinlerle alınan $A, C$ ve $E$ vitaminleridir. ${ }^{15}$

A vitamini hem hücre DNA'sının korunmasında hem de fagositik hücrelerin oto oksidatif hasardan korunmasında rolü vardır. ${ }^{16-17}$ Anti-oksidan özellikleri nedeniyle karotenoidler, patogenezlerinde oksidatif stresin rol aldığı düşünülen birçok kronik hastalığın tedavisinde ya da bu hastalıklardan korunma amaciyla denenmektedir. ${ }^{15}$ A vitamini beyinde dopamin, serotonin ve noradrenalin (NA) metabolizması üzerinde düzenleyici etkilere sahiptir. ${ }^{18}$ Ayrıca vitamin A eksikliğinin hayvan deneylerinde öğrenme ve belleği olumsuz etkilediği de gösterilmiştir. ${ }^{19}$ Vitamin C (askorbik asit) en güçlü anti-oksidan etkisini lipid peroksidasyonunu tetikleyen radikallerin etkilerini yok ederek gösterir. Böylece hücre membran ve DNA'sını hasardan korur. Askorbik asit ayrıca dopamini NA'ya çeviren dopamin $\beta$-hidroksilazın kofaktörüdür. Yine hem glutamat hem de dopamin aracilı nörotransmisyonda rolü olan bir nöromodülatördür. ${ }^{20}$ Vitamin $\mathrm{E}$ anti-oksidan olarak en önemli görevi, hücre membran lipidlerindeki çoklu doymamış yağ asitlerini serbest radikal hasarından korumaktır. ${ }^{15}$ Anti-oksidan etkisine ek olarak hücrede gen ekspresyonu regülasyonunda, hücre içi sinyal iletiminde ve hücresel proliferasyonunun modülasyonunda rol alır. ${ }^{21}$

Çocuk ve ergen DEHB hastalarında oksidatif metabolizmayı değerlendirmeye dönük son yıllarda artan çalışma sayısına rağmen anti-oksidan savunmaların önemli bir ayağı olan anti- oksidan vitamin düzeylerini araştıran çalıșma bulunmamaktadır. Bu çalışmada DEHB tanısı konan çocuk ve ergenlerin plazma $A, C$ ve $E$ vitamin düzeylerinin sağlıklı çocuk ve ergenler ile karşılaştırılması amaçlanmıştır.

Çalışmanın varsayımları; DEHB grubunda kontrollere göre plazma $A, C$ ve $E$ vitamin düzeylerinin düşük olacağı şeklindedir.

\section{Gereç ve Yöntem}

Çalı̧̧mamıza Hacettepe Üniversitesi Çocuk ve Ergen Ruh Sağllğı ve Hastalıkları Polikliniği’ne başvuran, psikiyatrik değerlendirmelerinde DSM-IV tanı ölçütlerine göre DEHB tanısı alan 39 hasta alındı. Çalışmaya alınan DEHB grubunda ek psikiyatrik, nörolojik ve metabolik hastalıklar dışlandı. Araştırmanın kontrol grubu ise çeşitli yakınmalarla polikliniğimize başvuran yapılan değerlendirmelerinde herhangi bir psikopatoloji saptanmayan 25 çocuk ve ergenden oluşturuldu. Alınan ayrıntılı öykü ve yapılan nörolojik muayane sonucunda nörolojik hastalık şüphesi olan hastalar çalışma dışı bırakıldı. Metabolik hastalık öyküsü ve/veya hastane başvurusu bulunanlar çalışmaya alınmadı. Yine vücut kitle indeksi değerleri hesaplanarak büyüme gelişme geriliği veya obezitesi olan katılımclar ile herhangi bir nedenle özel beslenme diyeti ya da ilaç alanlar çalışmadan çıkarıldı. Katılımcllardan son 1 hafta içinde enfeksiyon, enflamasyon, travma öyküsü tespit edilenler çalışmaya dahil edilmedi. Gönüllülük esasına göre çalışmaya dahil edilen katılımcılar ve ailelerinden yazılı onam alındı. Araştırma, Ankara 3 No'lu Klinik Araştırmalar Etik Kurulu tarafından onaylandı (dosya no: 2009-2539).

Tüm katılımcılar, DSM-IV tanı ölçütlerinin esas alındığı, yarı yapılandırılmış bir görüşme olan Çocuk ve Gençler için Duygulanım Bozukluğu ve Şizofreni ölçeği-Şimdi ve Yaşam Boyu Versiyonu (K-SADS-PL; Schedule for Affective Disorders and Schizophrenia for School Aged Children- Present and Lifetime Version) ${ }^{22}$ ile değerlendirildi. Araştırmanın tanı aşaması Conners Öğretmen Derecelendirme ölçeği (Conners' Teacher Rating scale ${ }^{23}$ ve ebeveynler tarafından doldurulan Çocuk ve Ergenlerde Davranım Bozuklukları için DSM-IV'ye Dayalı Tarama ve Değerlendirme ölçeği (YDB-TDÖ) ${ }^{24}$ ile desteklendi. K-SADS-PL ile DEHB grubu alt tipleri ayrımı yapıldı ve eş tanılar araştırıldı. DEHB grubunda karşı olma karşı gelme bozukluğu (KOKGB) dışında ek psikiyatrik tanı alanlar çalışma dışında bırakıldı. Katılımciların ailelerinin sosyo-ekonomik-sosyokültürel düzeyini belirlemek amaciyla, Hollingshead-Redich ${ }^{25}$ ölçeği kullanıldı.

Katılımcılardan bir gecelik açlığın ardından periferik venden 5 cc kan alındı. Alınan kan örnekleri Hacettepe Üniversitesi Metabolizma Laboratuvarı'nda santrifüj edilerek serumlar ayrıldı ve $-80^{\circ} \mathrm{C}$ 'de analiz yapılıncaya kadar saklandı. Vitamin $C$ düzeyi kalorimetrik yöntemle bakıldı. Vitamin A ve E düzeyleri ise yüksek basınçlı sıvı kromatografi sisteminde immuchrom hazır ticari kiti kullanılarak çalışıldı. Ölçümlerin referans aralığı A vitamini için 316-820 $\mu \mathrm{g} / \mathrm{L}, \mathrm{C}$ vitamini için $4-21 \mathrm{mg} / \mathrm{L}$, ve E vitamini için 6,6-14,3 mg/L'dir. 


\section{İstatistiksel Analiz}

Çalışmamızın istatistiksel analizleri SPSS 15.0 programı kullanılarak yapıldı. Dağılımların normalliği normallik testleri (Kolmogorov-Smirnov ve Shapiro-Wilk) ve görsel araçlar (histogram) kullanılarak değerlendirildi. Sürekli değişkenlerde bağımsız 2 grup karşılaştırılmasında Student's t-test, 3 grup karşılaştırılmasında ise ANOVA testi kullanıldı. Katogerik verilerin karşılaştırılmasında çapraz tablolar yapılarak değerlendirilmelerinde ki-kare testi kullanıldı. Kullanılan ölçekler ile değişkenler arasındaki ilişkiyi değerlendirmek için ise Pearson'ın bağıntı analizi uygulandı. Tüm istatistiksel işlemlerde anlamlılık düzeyi en az $\mathrm{p} \leq 0,05$ olarak kabul edildi.

\section{Bulgular}

Katılımcıların 39'u DEHB grubuna, 25'i kontrol grubuna aitti. DEHB grubu yaş ortalamaları [ \pm standart sapma (SS)] 120,1 $\pm 23,1$ ay iken kontrol grubu yaş ortalamaları $( \pm$ SS $) 123,7 \pm 26,4$ ay olup, iki grup yaş ortalamaları arasında istatistiksel olarak anlamlı bir fark gözlenmedi $(\mathrm{p}=0,781)$. Çalışmamızda yer alan DEHB grubunun 11'i (\%28,2) k1z 28'i erkek $(\% 71,8)$ iken, kontrol grubunun 7'si kız (\%28) 18'i erkek (\%72) olup, cinsiyetler açısından gruplar arasında fark yoktu $(\mathrm{p}=0,941)$. Yine her iki grup sosyo-ekonomik düzeyleri açısından birbirlerine benzer özellikler göstermekteydi.

Her iki grubun serum A ve E vitamin düzeyleri ortalamaları birbirlerine benzer olup gruplar arasında istatistiksel olarak anlamlı fark bulunmadı. Serum $C$ vitamin düzeylerinin ise DEHB grubunda, istatistiksel anlamlllık olmamakla birlikte, kontrol grubuna göre düşük düzeyde olduğu görüldü. DEHB ve kontrol gruplarına ait serum $\mathrm{A}, \mathrm{C}$ ve $\mathrm{E}$ vitamin değerleri Tablo 1'de verilmiştir.

DEHB hastalarının 16'sında (\%41) KOKGB eş tanısı vardı. KOKGB eş tanısı olmayan DEHB grubu, KOKGB eş tanısı olan DEHB grubu ve kontrol grubu arasinda da serum A vitamini $(p=0,401), C$ vitamini $(p=0,092)$ ve $E$ vitamini $(p=0,591)$ değerleri açısından istatistiksel olarak anlamlı fark gözlenmedi. Her üç gruba ait ortalama değerler ve istatistik sonuçları Tablo 2'de özetlenmiştir.

DEHB grubunda kullanılan CÖDÖ ölçeği toplam puanı ile serum A vitamini düzeyleri arasında $(r=0,294, p=0,069)$ zayıf

Tablo 1. Hasta ve kontrol grupları A, $C$ ve $E$ vitamin düzeyleri $(\mu \mathrm{mol} / \mathrm{L})$

\begin{tabular}{|c|c|c|c|}
\hline & $\begin{array}{l}\text { DEHB (n=39) } \\
\text { (ortalama } \\
\pm \text { standart } \\
\text { sapma) }\end{array}$ & $\begin{array}{l}\text { Kontrol }(\mathrm{n}=25) \\
\text { (ortalama } \\
\pm \text { standart } \\
\text { sapma) }\end{array}$ & Istatistik \\
\hline A vitamini $(\mu g / L)$ & $449 \pm 81$ & $473 \pm 110$ & $\begin{array}{l}t=0,992 \\
p=0,325\end{array}$ \\
\hline$C$ vitamini $(\mathrm{mg} / \mathrm{L})$ & $6,46 \pm 3,3$ & $8,01 \pm 4,1$ & $\begin{array}{l}t=1,585 \\
\mathrm{p}=0,097\end{array}$ \\
\hline E vitamini (mg/L) & $11,32 \pm 1,7$ & $10,95 \pm 1,7$ & $\begin{array}{l}\mathrm{t}=-0,820 \\
\mathrm{p}=0,415\end{array}$ \\
\hline
\end{tabular}

DEHB: Dikkat eksikliği ve hiperaktivite bozukluğu ilişki saptanırken serum $C$ vitamin düzeyleri arasında $(r=217$, $\mathrm{p}=0,184)$ ve serum $\mathrm{E}$ vitamin düzeyleri arasında $(\mathrm{r}=0,145$, $\mathrm{p}=0,343)$ ilişki saptanmamıştır. Yine YDB-TDÖ ölçeği toplam puanı ile serum A vitamin düzeyleri arasinda $(r=0,156, p=0,307)$, serum $C$ vitamin düzeyleri arasında $(r=0,031, p=0,841)$ ve serum E vitamin düzeyleri arasında da $(r=0,019, \mathrm{p}=0,908)$ istatistiksel ilişki saptanmadı.

Çalışmaya alınan DEHB grubunun \%49'u ( $\mathrm{n}=19)$ DEHB bileşik tip (DEHB-B), \%33'ü ( $n=13)$ DEHB dikkatsizliğin önde geldiği tip (DEHB-DE) ve \%18'i ( $\mathrm{n}=7$ ) DEHB hiperaktivite-dürtüselliğin önde geldiği tip (DEHB-H/D) tanısı aldı. Her üç DEHB alt tipinin karşılaştırıldığı analizlerde serum vitamin düzeyleri açısından fark tespit edilmedi (A vitamini için; $p=0,519, F=0,668, C$ vitamini için; $p=0,599, F=0,520$ ve $E$ vitamini için; $p=0,111$, $\mathrm{F}=2,33$ ).

\section{Tartışma}

DEHB'de oksidatif stresin rolü olabileceğini iddia eden çalışmalar bulunmasına rağmen çocuk ve ergen hasta grubunda antioksidan vitamin düzeylerine dair çalışma bulunmamaktadır. Erişkin grupta yapılan tek çalışmada A ve E vitamin düzeyleri çalışılmış; DEHB hastaları ve kontrol grubu arasında anlamlı fark bulunmamıştır. ${ }^{26} \mathrm{Bu}$ konuda çok sınırlı sayıda çalışma yapılmış olmasının en önemli nedeni oksidatif metabolizma çalışmalarının DEHB'de görece yeni bir konu olması ve vitamin düzeyi çalışmanın teknik olarak zorluğu olabilir. Çalışmamızda A ve E vitamin düzeyleri sağlıklı kontrollere benzer bulunurken $C$ vitamin düzeyi, istatistiksel anlamlılık olmamakla beraber, düşük bulundu. Daha geniş gruplar ile yapılacak çalışmalar $C$ vitamin düzeyindeki olası farkları göstermek açısından yol gösterici olabilir.

Güçlü anti-oksidan etkileri olan A, C ve E vitaminleri anti-oksidan savunma mekanizmalarının bir parçasını oluşturmaktadır. Vücudumuzda toplam anti-oksidan kapasiteye etki eden birçok bileşen bulunmaktadır. Dolayısıyla serum antioksidan vitamin düzeylerinde fark bulunmaması DEHB'de antioksidan savunmaların etkilenmediği anlamına gelmez. Özgül moleküllerdeki değişimlerin toplam anti-oksidan kapasiteye etkisi olmakla beraber bütünü göstermediği unutulmamalıdır.

Tablo 2. Yalnız DEHB, KOKGB eş tanısı olan DEHB ve kontrol grubunun $A$, $C$ ve $E$ vitamin değerleri

\begin{tabular}{|c|c|c|c|c|}
\hline & $\begin{array}{l}\text { Yalniz } \\
\text { DEHB } \\
(n=23) \\
\text { (ortalama } \\
\pm \text { standart } \\
\text { sapma) }\end{array}$ & $\begin{array}{l}\text { DEHB + } \\
\text { KOKGB } \\
(n=16) \\
\text { (ortalama } \\
\pm \text { standart } \\
\text { sapma) }\end{array}$ & $\begin{array}{l}\text { Kontrol } \\
\text { grubu } \\
\text { (n=25) } \\
\text { (ortalama } \\
\pm \text { standart } \\
\text { sapma) }\end{array}$ & İstatistik \\
\hline $\begin{array}{l}\text { A vitamini } \\
(\mu \mathrm{g} / \mathrm{L})\end{array}$ & $457 \pm 84$ & $437 \pm 77$ & $473 \pm 110$ & $\begin{array}{l}F=0,925 \\
p=0,401\end{array}$ \\
\hline $\begin{array}{l}\text { C vitamini } \\
(\mathrm{mg} / \mathrm{L})\end{array}$ & $6,35 \pm 3,2$ & $6,62 \pm 3,5$ & $8,01 \pm 4,1$ & $\begin{array}{l}F=2,470 \\
p=0,092\end{array}$ \\
\hline $\begin{array}{l}\text { E vitamini } \\
(\mathrm{mg} / \mathrm{L})\end{array}$ & $11,45 \pm 1,8$ & $11,14 \pm 1,5$ & $10,95 \pm 1,7$ & $\begin{array}{l}F=0,533 \\
p=0,591\end{array}$ \\
\hline
\end{tabular}

DEHB: Dikkat eksikliği ve hiperaktivite bozukluğu, KOKGB: Karşı olma karşı gelme bozukluğu 
Bununla beraber, anti-oksidan seviyenin normalin üstünde olduğu durumlarda dahi oksidatif imbalanstan söz edilebileceği gösterilmiştir. ${ }^{11} \mathrm{Bu}$ nedenle ileri çalışmalarda anti-oksidan vitamin düzeylerinin toplam oksidan ve anti-oksidan kapasite ile birlikte değerlendirilmesi önerilebilir.

Çalışmamız, çocuk ve ergen grup DEHB'de anti-oksidan vitamin düzeylerinin araştırıldığı ilk çalışma olma özelliğine sahiptir. Psikiyatrik hastalıklarda anti-oksidan vitamin düzeylerini araştıran çalışmalar sınırlıdır. Otizm hastalarında Guo ve ark. ${ }^{27} \mathrm{~A}$ vitamin düzeyinin, Bakkaloğlu ve ark. ${ }^{28} \mathrm{~A}, \mathrm{C}$ ve $\mathrm{E}$ vitamin düzeylerinin, Al-Gadani ve ark. ${ }^{29}$ ise vitamin $\mathrm{E}$ düzeyinin azalmış olduğunu bildirmişlerdir. Şizofreni hastalarının sağlıklı kontrollerle karşılaştırıldığı iki ayrı çalışmada serum $C$ ve $E$ vitamin seviyeleri düşük bulunmuştur. ${ }^{30-32}$ Guatam ve ark. ${ }^{33}$ ise yaygın anksiyete bozukluğu ve depresyon hastalarında $\mathrm{A}, \mathrm{C}$ ve $\mathrm{E}$ vitamin düzeylerinin sağllklı kontrollere göre düşük olduğunu bildirmişlerdir. ${ }^{33}$

Psikiyatrik hastalıklarda anti-oksidan vitamin ekleme tedavileri ile ilgili olumlu sonuçlar bildiren çalışmalar vardır. Literatürde vitamin ekleme tedavilerinin kullanımı anti-oksidan savunmayı güçlendirme, besinlerle yetersiz alıma bağlı eksikliğin giderilmesi ve bazı anti-psikotik ilaçların üretimini arttırdığı reaktif oksijen radikallerine karşı koruyucu amaçlı olmak üzere üç ayrı koşulla ilişkilendirilmiştir. ${ }^{34}$ Dolske ve ark. ${ }^{35}$ otistik hasta grubunda yaptıkları çift kör plasebo kontrollü bir çalışmada, askorbik asit ekleme tedavisi ile kanat çırpma, sallanma ve dönme gibi stereotipik hareketlerde belirgin iyileşme olduğunu belirtilmişlerdir. İki ayrı çalışmada ise şizofreni hastalarında anti-psikotik tedaviye ek olarak verilen anti-oksidan vitaminlerin hastalık belirtilerinde belirgin düzelmeye neden olduğu bildirilmiştir. ${ }^{36-38}$ Guatam ve ark. ${ }^{33} \mathrm{~A}, \mathrm{C}$ ve $\mathrm{E}$ vitamin düzeyini düşük buldukları yaygın anksiyete ve depresyon hastalarında 6 haftalık vitamin destek programından sonra, hastaların A ve $C$ vitamin düzeylerinin normale döndügünü ve bununda hastaların ölçek skorlarında düzelme ile beraber olduğunu belirtmiş̧lerdir. DEHB'de anti-oksidan vitamin ekleme tedavilerine dair yeterli veri bulunmamaktadır. Gren ve ark. ${ }^{39}$ anti-oksidan özellikleri olan yüksek doz vitamin kullandıkları çalışmalarında, belirgin bir etki gözlenmediğini bildirmişlerdir. Joshi ve ark. ${ }^{40}$ ise Omega 3 ve vitamin $C$ kombinasyonunun birlikte kullanımının DEHB belirtilerinde azalmaya yol açtığını bulmuşlardır.

Her ne kadar olumlu sonuçlar bildiren çalışmalar olsa da; anti-oksidan vitaminlerin vücutta optimum miktarın üzerine çıktığında nasıl etkide bulundukları net olarak aydınlatılamamıştır. ${ }^{34}$ Vitamin A ve C'nin bazı koşullarda antioksidan olarak işlev göstermedikleri; aksine prooksidan olarak işlev gösterebilecekleri gösterilmiştir. ${ }^{41,42}$ Ayrıca bu tedaviler sırasında gelişebilecek hipervitaminozlar durumlarına karşı dikkatli olunması gerekmektedir. ${ }^{43}$ Eldeki veriler ışığında vitamin takviyelerinin olgu düzeyinde ele alınması, birincil önceliğin tespit edilen eksikliği gidermek ve optimum kan düzeyini sağlamak olması gerektiği önerilebilir.

\section{Çalışmanın Kısıtlılıkları}

$\mathrm{Bu}$ çalışmanın en önemli sınırlılığı vitamin düzeylerinin yalnızca periferik kanda bakılmış olmasıdır. Sağlıklı bireylerde periferik kan ve beyin omirilik sıvısı (BOS) vitamin düzeyleri korele olmakla beraber alzheimer, demans gibi çeşitli klinik durumlarda değişimler olduğu bildirilmiştir. Ayrıca vücudumuzda oksijenin birim ağırlık başına en fazla kullanıldığı organ beyin dokusudur (Shulman ve ark. ${ }^{44}$ ). Dolayısı ile reaktif oksijen türlerinin en yoğun açığa çıktığı yer de beyin dokusudur. Bunun yanında beyin dokusunun anti-oksidan kapasitesinin sinırlı olması ve yine yüksek lipit ve demir yoğunluğuna sahip olması, beyin dokusunu serbest radikal hasarına daha duyarlı kılmaktadır (Chauhan ve Chauhan ${ }^{45}$ ). Tüm bu nedenlerden dolayı ileri çalışmalarda bu parametrelerin BOS seviyelerinin araştırılması konu hakkında daha önemli veriler sağlayabilir. Çalışmanın bir diğer sınırlılığı ise olgu sayılarının azlığıdır. K-SADS-PL yapılarak ek tanıların dışlanmış olması, hastaların herhangi bir tedavi almamış olmaları çalışmanın güçlü yanlarıdır.

\section{Sonuç}

Çalışmamızın sonuçları anti-oksidan vitamin düzeylerinin DEHB tanısı konulan hastalarda sağlıklı kontrollerden farklı olmadığını göstermiştir. İstatistiksel düzeyde anlamlı olmamakla beraber serum $C$ vitamini düzeyinde tespit edilen azalmanın, daha geniş gruplar ile yapılacak çalışmalarda değerlendirilmesi önerilir.

\section{Etik}

Etik Kurul Onayı: Araştırma, Ankara 3 No'lu Klinik Araştırmalar Etik Kurulu tarafından onaylandı (dosya no: 2009-2539).

Hasta Onayı: Alındı.

Hakem Değerlendirmesi: Editörler kurulu ve editörler kurulu dışında olan kişiler tarafından değerlendirilmiştir.

\section{Yazarlık Katkıları}

Konsept: M.K., M.Z.K., S.Ö., F.Ü., Dizayn: M.K., M.Z.K., S.Ö., F.Ü., Veri Toplama veya İşleme: M.K., M.Z.K., S.Ö., F.Ü., Analiz veya Yorumlama: M.K., M.Z.K., S.Ö., F.Ü., Literatür Arama: M.K., M.Z.K., S.Ö., F.Ü., Yazan: M.K., M.Z.K., S.Ö., F.Ü.

Çıkar Çatışması: Yazarlar tarafından çıkar çatışması bildirilmemiştir.

Finansal Destek: Yazarlar tarafından finansal destek almadıkları bildirilmiştir.

\section{Kaynaklar}

1. Barry Halliwell. Antioxidant defence mechanisms: From the beginning to the end (of the beginning). Free Radical Research. 1999;31:261-272.

2. Kannan K, Jain SK. Oxidative stress and apoptosis. Pathophysiology. 2000; 7:153-163.

3. Haddad JJ. Oxygen sensing and oxidant/redox-related pathways. Biochemical and Biophysical Research Communications. 2004;316:969-977.

4. Zoroğlu SS, Herken H, Yurekli M, Uz E, Tutkun H, Savaş HA, Bagci C, Ozen ME, Cengiz B, Cakmak EA, Dogru MI, Akyol O. The possible pathophysiological role of plasma nitric oxide and adrenomedullin in schizophrenia. Journal of Psychiatric Research. 2002;36:309-315. 
5. Paşca SP, Nemes B, Vlase L, Gagyi CE, Dronca E, Miu AC, Dronca M. High levels of homocysteine and low serum paraoxonase 1arylesterase activity in children with autism. Life Sciences. 2006;78:2244-2248.

6. Ceylan MF, Şener S, Bayraktar AC ve ark. Changes in oxidative stress and cellular immunity serum markers in attention-deficit/ hyperactivity disorder. Psychiatry Clin Neurosci. 2012;66:220-226.

7. Ceylan M, Sener S, Bayraktar AS ve ark. Oxidative imbalance in child and adolescent patients with attention-deficit/ hyperactivity disorder. Progress in Neuro-Psychopharmacology \& Biological Psychiatry. 2010;34:1491-1494.

8. Can M, Güven B, Atik L, Konuk N. Lipid peroxidation and serum antioxidant enzymes activity in patients with bipolar and major depressive disorders. Journal of Mood Disorders 2011;1:14-18.

9. Nasim S, Naeini AA, Najafi $M$ ve ark. Relationship between antioxidant status and attention deficit hyperactivity disorder among children. Int J Prev Med. 2019;10:41.

10. Felicity Ng, Michael Berk, Olivia Dean, Ashley I. Bush, Oxidative stress in psychiatric disorders: evidence base and therapeutic implications. International Journal of Neuropsychopharmacology. 2008;11:851-876

11. Selek S, Bulut M, Ocak AR, Kalenderoglu A, Savas H. Evaluation of total oxidative status in adult attention deficit hyperactivity disorder and its diagnostic implications. J Psychiatr Res 2012;46:451-455.

12. Yorbık O, Cansever A, Söhmen T. Otizmde nörönal görüşler. Çocuk ve Gençlik Ruh Sağlığ1 Dergisi. 2002;9:118-127.

13. Mahadik SP, Mukherjee S. Free radical pathology and antioxidant defense in schizophrenia:a review. Schizophrenia Res . 1996;19:1-17.

14. Reddy RD, Yao JK. Free radical pathology in schizophrenia:a review. Prostaglandins Leukot Essent Fatty Acids. 1996;55:33-43.

15. Sencer E ve Orhan Y. Vitaminler. "Klinik Beslenme" 1. baskı içinde. Sencer E ve Orhan Y (ed). Çapa-istanbul: İstanbul Medikal Yayıncllık. 2005;s:166-187.

16. Sies H, Stahl W, Sundquist AR. Antioxidants function of vitamins E and C, beta carotene and other carotenoids. Ann NY Acad Sci. 1992;30:7-20.

17. Rao AV, Ray MR, Rao LG. Lycopene. Adv Food Nutr Res. 2006;51:99164.

18. O'Reilly KC, Trent S, Bailey SJ, Lane MA. 13-cis-retinoic acid alters intracellular serotonin, increases 5-HT1A receptor, and serotonin reuptake transporter levels in vitro. Exp Biol Med (Maywood) 2007;232:1195-1203.

19. Cocco S, Diaz G, Stancampiano R, Diana A, Carta M, Curreli R et al. Vitamin A deficiency produces spatial learning and memory impairment in rats. Neuroscience. 2002;115:475-482.

20. Rice ME. Ascorbate regulation and its neuroprotective role in the brain. Trends Neurosci. 2000;23:209-216.

21. Takada T, Suzuki H. Molecular mechanisms of membrane transport of vitamin E. Mol Nutr Food Res. 2010;54:616-622.

22. Gökler B, Ünal F, Pehlivantürk B, Çengel Kültür SE, Akdemir D, Taner Y. Okul çağı çocukları için duygulanım bozuklukları ve şizofreni görüşe çizelgesi şimdi ve yaşam boyu versiyonu - Türkçe versiyonu'nun (ÇDSG-SY-T) geçerlilik ve güvenirliği. Çocuk ve Gençlik Ruh Sağlığı Dergisi. 2004; 11:109-116.

23. Dereboy Ç, Şenol S, Şener Ş, Dereboy F. Conners Kısa Form Öğretmen ve Ana Baba Derecelendirme Ölçeklerinin Geçerliği. Türk Psikiyatri Dergisi. 2007;18:48-58.

24. Turgay, A. Çocuk ve ergenlerde davranım bozuklukları için DSMIV'e dayalı tarama ve değerlendirme ölçeği (Yayınlanmış Ölçek). Integrative Therapy Institute,Toronto : Kanada. 1995

25. Hollingshead AB, Redlich F C. Social class and mental illness: A community study. New York: Wiley. 1958.

26. Landaas ET, Aarsland TIM, Ulvik A ve ark.Vitamin levels in adults with ADHD. BJPsych Open. 2016;2:377-384
27. Guo M, Zhu J, Yang T ve ark. Vitamin A and vitamin D deficiencies exacerbate symptoms in children with autism spectrum disorders. Nutritional Neuroscience. 2018;16:1-11.

28. Bakkaloğlu B . Otistik bozuklukta antioksidan enzim ve antioksidan vitamin düzeyleri, malondialdehit ve glutatyon düzeyleri (Uzmanlık tezi). Ankara, Hacettepe Üniversitesi. 2007

29. Al-Gadani Y, El-Ansary A, Attas O ve ark. Metabolic biomarkers related to oxidative stress and antioxidant status in Saudi autistic children. Clin Biochem. 2009;42:1032-1040.

30. Derin D, Yazıcı A, Erkoç Ş. Şizofrenik bozukluğu olan hastalarda serbest radikal metabolizması ve nonenzimatik antioksidan savunma sistemi elemanlarının incelenmesi. Klinik Psikofarmakoloji Bülteni. 2001;11:174-182.

31. Dadheech G, Mishra S, Gautam S ve ark. Oxidative stress, $\alpha$-tocopherol, ascorbic acid and reduced glutathione status in schizophrenics. Indian J Clin Biochem. 2006;21:34-38.

32. Kılıçgün H, Erşan EE, Bakır S, ve ark. Xanthine oxidase, adenosine deaminase and vitamin E levels in patients with schizophrenia. Anadolu Psikiyatri Dergisi. 2016;17:476-481.

33. Guatam M, Agrawal M, Guatam M ve ark. Role of antioxidants in generalised anxiety disorder and depression. Indıan J Psychiatry. 2012;54:244-247.

34. Mazlum B. Antioksidan Vitaminler ve Psikiyatride Kullanımı. Psikiyatride Güncel Yaklaşımlar-Current Approaches in Psychiatry. 2012;4:486-505.

35. Dolske MC, Spollen J, McKay S ve ark. A preliminary trial of ascorbic acid as supplemental therapy for autism. Prog Neuropsychopharmacol Biol Psychiatry. 1993;17:765-774.

36. Dakhale GN, Khanzode SD, Khanzode SS ve ark. Supplementation of vitamin $C$ with atypical antipsychotics reduces oxidative stress and improves the outcome of schizophrenia. Psychopharmacology (Berl). 2005;182:494-498.

37. Sivrioglu EY, Kirli S, Sipahioglu D ve ark. The impact of omega-3 fatty acids, vitamins $E$ and $C$ supplementation on treatment outcome and side effects in schizophrenia patients treated with haloperidol: an open-label pilot study. Prog Neuropsychopharmacol Biol Psychiatry. 2007;31:1493-1499.

38. Arvindakshan M, Ghate M, Ranjekar PK, Evans DR, Mahadik SP. Supplementation with a combination of omega-3 fatty acids and antioxidants (vitamins $\mathrm{E}$ and $\mathrm{C}$ ) improves the outcome of schizophrenia. Schizophr Res. 2003;62:195-204.

39. Green WH. The treatment of attention deficit hyperactivity disorder with nonstimulant medications. Child Adolesc Psychiatric Clin North Am. 1995;4:169-195.

40. Joshi K, Lad S, Kalea M ve ark. Supplementation with flax oil and vitamin $C$ improves the outcome of attention deficit hyperactivity disorder. Prostaglandins, Leukotrienes and Essential Fatty Acids. 2006;74:17-21.

41. Gelain DP, Bittencourt Pasquali MA, Caregnato FF, Moreira JC. Vitamin A (retinol) up-regulates the receptor for advanced glycation endproducts (RAGE) through p38 and Akt oxidant-dependent activation. Toxicology. 2011;289:38-44.

42. Buettner GR, Jurkiewicz BA. Cataliytic metals, ascorbate and free radicals: combinations to avoid. Radiat Res. 1996;145:532-541.

43. Kimmoun A, Leheup B, Feillet F, Dubois F, Morali A. Hypercalcemia revealing iatrogenic hypervitaminosis $\mathrm{A}$ in a child with autistic troubles. Arch Pediatr. 2008;15:29-32.

44. Shulman RG, Rothman DL, Behar KL ve ark. Energetic basis of brain activity:implications for neuroimaging. Trends Neurosci. 2004;27:489-495.

45. Chauhan A, Chauhan V. Oxidative stress in autism. Pathophysiology. 2006;13:171-181. 